\title{
Classroom Observation as a Tool for Professional Development
}

\author{
Aisha Siddiqua $^{1}$ \\ ${ }^{1}$ Beaconhouse School System, Hafizabad, Pakistan \\ Correspondence: Beaconhouse School System, Pakistan; Yanbu English Language Institute, Royal Commission, \\ Yanbu, Saudi Arabia.
}

Received: January 25, 2019

Accepted: February 18, 2019 Online Published: February 22, 2019

doi:10.5430/wjel.v9n1p49

URL: https://doi.org/10.5430/wjel.v9n1p49

\begin{abstract}
The study indicates that classroom observation is potentially a useful tool for teachers' professional development and works best when the personal capacity of a teacher, an observer, and school provide a base for the effective use and outcome for teachers.

A brief summary of major findings and lessons learnt from the project, process, learning of teachers and my own learning is presented as follows;

i) Teachers found the pre and post-observation sessions very useful for their professional development. These sessions also help the observer to understand the roots of the teacher's classroom problems.

ii) Cyclical observations provide the courage and intellectual capacity to the teachers to turn their focus upon improved actions and they also developed their professional skills.

iii) Teachers perceived my role as a helper, facilitator and a resource person who could provide suggestions and alternatives, where needed.

I feel the need to further explore, how reflective conversations between a teacher and an observer affect individual teacher's attitudes and behaviour. This will highlight what needs to be done further to improve individual competencies. However, I feel that a co-teaching experience can also provide a valuable basis for collaborative inquiry. It might raise a range of interesting issues and questions for using reflective conversation in planning, teaching, and improving this strategy.
\end{abstract}

Keywords: lesson observation, tutoring/mentoring, reflective teaching, teacher development, reflective diary

\section{Introduction}

In this paper, I shall try to outline the process and consequences of classroom observation for teachers' professional development. This paper includes four sections. Section one presents a brief description and analysis of the context-both my own and my institution. Section two narrates a brief review of the literature supporting different approaches and methods of classroom observation. Section three contains a description, analysis, and review of my practical project. Section four talks about the lessons learnt and a proposed action plan based on the outcomes of my project.

My current professional experience as a teacher informs me that teachers require professional support to develop their reflective skills to respond critically to various situations and events that they face inside and outside their classrooms. In order to provide professional support, classroom observation has been emphasized greatly to make teachers active and ongoing learners (Schon, 1983) and has the potential to lead to transformative thinking and learning (Dewey 1933, Zeichner and Liston 1996). During my professional practice, I have been observed by my school head, a number of times. However, the notion of classroom observation, in my mind, has always been intimately linked with being a pure examination and judgment of my ability as a teacher. There are some solid reasons for this perception since each time when I was observed, was a specific time. For instance, when I was hired, a mandatory observation was taken before I received my appointment letter. Later I was observed before my confirmation. Subsequent observations are usually conducted prior to the annual appraisals. Thus, my perception of an observer has been of an austere examiner: a judge who dispassionately appraises and calculates what I do right or wrong and in the end informs me about my weaknesses as a teacher. The feedback session is generally a short formal session without any chance of a detailed discussion. Observations in my experience have always produced feelings 
of defensiveness and insecurity because they have a direct influence on my career prospects as my professional strengths and weaknesses are graded against certain norms and standards.

The notion of observation's purpose and the observer's role has had a profound imprint on how I conducted the observations, after I became the school head. While observing teachers I found that they apply their tested strategies and avoid trying any new strategy in the fear of going unsuccessful. Therefore, such observations lead to an emphasis on displaying teaching skills for one lesson only (Maingay 1988). Rowe (1973) also points out, "If we feel that we are being judged, we lose the (...) courage to try new ideas and explore freely" (In Gebhard. 1990:308).

In short, there is no concept of observation for the purpose of development, and involving the teacher in collaborative dialogue to help her reflect and evaluate her practices. Gebhard (1984) and Edge (1992) emphasize the importance of exploring ideas with the teacher. Pre-observation session is considered a luxury, therefore, has never been welcomed in school, whereas this scaffolding involves the teacher in the process of reflection, examination, and change, which can lead to personal and professional development (Freeman 1982, Schon, 1983) and further helps them to become "self-propelling" and "self-actualizing" (Lewis and Miel 1972).

During my study, I was exposed to different purposes and approaches of classroom observation or teachers' professional development that helped me re-conceptualize my understanding of the outcomes of classroom observation. Therefore, I planned to conduct the observations to help teachers develop their professional skills and extend their teaching repertoire.

\section{Literature Review}

The importance of developing reflective practice as an element of teacher practice is reflected in the work of Roberts (2009), who considers it a vital element in any work-related experience to maximize learning; Fook and Gardner (2007), who suggest that critical reflection is essential to support the examination of personal bias and to consider both theory and practice in the workplace; and McLeod (2015), Hickson (2011) and Canada-Phillips (2014), who all implement reflective practice to develop a more critical way of interacting in diverse teaching and learning contexts. Additionally, the role of activities designed to support the development of skills in reflection as an integrated element of teacher preparation courses is discussed by Williamson, Mears and Bustos (2015) and also by Bulman, Lathlean and Gobbi (2014) as an important aspect of preparation for individuals entering the caring professions in order to develop their capacities to become reflective practitioners. Similarly, Hargreaves (2016), Paterson and Chapman (2013), Dervent (2015) and Liu (2015) argue the importance of these activities in exclusively educational preparation contexts. Again, the importance of criticality is highlighted. McGarr and Cormack (2014) warn that implementing reflective practices without the critical lens is not only ineffective in promoting change, but can actually reinforce the dominant perspective and serve to maintain the status quo. Collin, Karsenti, and Komis (2013) voice their concerns that, at a time when critical reflective practice is becoming more important, it has the potential to become yet another educational 'buzzword' or 'another catchword for education reform.' They express concerns about the lack of certainty around what works effectively to assist pre-service teachers in the development of critical reflection skills and the complexities of assessing these skills. The complexities of developing pre-service teachers' skills in critical reflective practice were realized by Körkkö, Kyrö-Ammälä, and Turunen (2016), who found that Finnish pre-service teachers lacked the skills of critical reflection that could promote change in their educational contexts. What is important about the notions of reflection discussed, is that irrespective of your starting point; you do need to engage in each of these aspects of reflection described.

Literature provides a comprehensive framework for classroom observation that leads to the professional development of teachers. Goldhammer (1969) presents a "Cyclical Model of Supervision" including five steps and Cogan (1973) describes a "Clinical Model of Supervision" consisting of the eight steps as an effective approach towards teachers" professional development. Acheson and Gall (1987), Gaies and Bowers (1990) and Randall and Thornton (2001) further simplify by including three steps. 
The following table outlines the steps from these models.

Table 1. Outline of Observation Steps within Clinical Supervision Cycle

\begin{tabular}{|c|c|c|c|c|}
\hline \multicolumn{2}{|c|}{ Goldhammer (1969) } & \multicolumn{2}{|l|}{ Cogan (1973) } & $\begin{array}{l}\text { Acheson and Gall (1987), } \\
\text { Gaies and Bowers (1990), Randall } \\
\text { and Thorntorn (2001) }\end{array}$ \\
\hline \multicolumn{2}{|c|}{ 1. Pre-observation } & $\begin{array}{l}\text { 1. Establishing teacher-super } \\
\text { 2. Planning with the teacher } \\
\text { 3. Planning the strategy of ob }\end{array}$ & $\begin{array}{l}\text { sor relationship } \\
\text { ervation }\end{array}$ & 1. Planning conference \\
\hline \multicolumn{2}{|c|}{ 2. Observation } & 4. Observing instruction & & 2. Observation \\
\hline $\begin{array}{l}\text { 3. Ana } \\
\text { for the } \\
\text { 4. Supe } \\
\text { 5. Post }\end{array}$ & $\begin{array}{l}\text { ysing and strategy planning } \\
\text { onference } \\
\text { vision conference } \\
\text { observation analysis }\end{array}$ & $\begin{array}{l}\text { 5. Analysing the teaching-lea } \\
\text { 6. Planning the strategy of the } \\
\text { 7. The conference } \\
\text { 8. Renewed planning }\end{array}$ & $\begin{array}{l}\text { ing process } \\
\text { conference }\end{array}$ & 3. Feedback conference \\
\hline \multicolumn{5}{|c|}{$\begin{array}{l}\text { Freeman (1982: 21) identifies three approaches where an observer leads the teacher by telling "what to do" when } \\
\text { first begin to teach to further providing alternatives to facilitate her "how to do" and lastly helps her to reflect on the } \\
\text { reasons behind choices and develop her own criteria for "why to do." Therefore, the role of an observer is about } \\
\text { drawing teachers' attention to the principles behind the rituals (Maingay 1988). Flanagan (1949 In Wragg. 1999) has } \\
\text { also developed "critical events" approach and is used for research purpose by Wragg 1984, 1993a; Wragg et al. 1996, } \\
\text { 1998, 1999) as Bollington et al. (1990) point out that some teachers find choosing areas of specific focus quite } \\
\text { difficult. The following table presents a summary of different approaches and models of supervision. }\end{array}$} \\
\hline \multirow[b]{2}{*}{ Stage } & Freeman (1982) & Freeman (1982) & Freeman (1982) & Gebhard (1990) \\
\hline & Teachers want to know & Observer's role & Approaches to observation & Models of supervision \\
\hline 1 & What do I teach? & $\begin{array}{l}\text { Authority } \\
\text { Arbitrator }\end{array}$ & Supervisory & $\begin{array}{l}\text { Prescriptive } \\
\text { Directive }\end{array}$ \\
\hline 2 & How do I teach what I teach? & $\begin{array}{l}\text { Provider of alternative } \\
\text { aspects }\end{array}$ & Alternative & $\begin{array}{l}\text { Nominal } \\
\text { Alternative }\end{array}$ \\
\hline 3 & $\begin{array}{l}\text { Why do I teach what I teach? } \\
\text { Why do I teach the way I do? }\end{array}$ & Understander & Non-directive & $\begin{array}{l}\text { Collaborative } \\
\text { Non-directive } \\
\text { Self-helped } \\
\text { Explorative }\end{array}$ \\
\hline
\end{tabular}

Study of literature led me to explore the process and consequences of observation for teachers' professional development, so I plan to conduct a series of cyclical observations using a combination of different approaches and models of supervision to help teachers develop their professional skills as Maingay (1988 In Duff. 1998) suggests that observation should be conducted in a series of lessons. I also plan to conduct the post-observation session the next day of observation as Randall and Thornton (2001) point out, "Soon after the lesson teacher may well be incapable of (...) make any sensible evaluation of the experience." Reflection on classroom practice is a deliberate, logical and systematic activity (Russell and Munby 1993 In Moon. 1999) that supports the teachers along their practices, so I plan to use a framework to analyse teachers' level of reflection in order to see the implementation of observation as a tool for teachers' professional development. (See Appendix 1)

\section{Description and Analysis of the Project}

I worked with two novice English teachers who volunteered to participate in the project. (See Appendix 2) The rationale for working with English teachers was to help them with content if needed since I also teach the same subject as Labrie et al. (2002) suggest, "Reflective conversations facilitate learning in a better way if participants teach a common subject." I used a consent form to request the teachers to become my project participants and assured them of confidentiality of data and anonymity by using pseudonyms. (See Appendix 3) Parents and pupils were also asked to give consent to video record the lessons. The project lasted for ten weeks altogether. Each teacher was observed once a week and five times in total. Before the beginning of the project, teachers introduced and described their pupils; provided an overview of the syllabus/course, their objectives, and perceived problems. Teachers also shared their doubts or fears with me. Teachers were clearly informed that the data gathered during their classroom observations and feedback will not be shared with the school management. Teachers were also given a comprehensive brief about how to compile their reflective diaries. Pupils reacted quite normal during all the observations as they had been informed and taken in confidence by their teachers about the presence of an observer in the room. 


\subsection{Intervention Phase}

Implementation phase included five cycles, i.e. five weeks of working with each teacher. During these cycles, I planned, observed and reflected upon each stage of pre, while and post-observation as a strategy for teachers' professional development. The following table outlines the observation cycles of my project.

Table 3. Table Showing an Outline of Implementation Cycles

\begin{tabular}{ll}
\hline \multicolumn{1}{c}{ Implementation Cycles } & \multicolumn{1}{c}{ Purposes } \\
\hline Cycle 1: Diagnostic observation & $\begin{array}{l}\text { Identify the areas of specific focus for subsequent observations. } \\
\text { Help teachers to identify critical events in their class. } \\
\text { Cycle 2: Observation of one agreed area }\end{array}$ \\
$\begin{array}{l}\text { Cycle 3: Observation of the implementation of mutually } \\
\text { Egreed strategies focusing on a specific area }\end{array}$ \\
$\begin{array}{l}\text { Cycle 4: Observation of the implementation of } \\
\text { co-planned strategies }\end{array} \begin{array}{l}\text { Provide scaffolding to teachers to reflect on their practice by sharing } \\
\text { observation notes with them. }\end{array}$ \\
$\begin{array}{l}\text { Cycle 5: Observation of the implementation of } \\
\text { alternative srovide teachers with a chance to look critically at their practice } \\
\text { observation }\end{array}$
\end{tabular}

I collected data using different data generation instruments and materials. The following table shows the tools that are used to collect data at each stage of the process.

Table 4. Table Showing Tools to Collect Data at Each Stage of the Process

\begin{tabular}{ll}
\hline \multicolumn{1}{c}{ Stages } & \multicolumn{1}{c}{ Tools to collect data } \\
\hline $\begin{array}{l}\text { Pre-observation: I plan to discuss } \\
\text { The aims, structure, and purpose of the lesson and the } \\
\text { way it will proceed. }\end{array}$ & $\begin{array}{l}\text { The audio recording of pre-observation sessions, teachers' } \\
\text { reflective diary, proposed lesson plans }\end{array}$ \\
$\begin{array}{l}\text { Observation: I plan to } \\
\text { - Collect information using different instruments. }\end{array}$ & $\begin{array}{l}\text { Observation checklists, video recording of the last } \\
\text { observation }\end{array}$ \\
$\begin{array}{l}\text { Post-observation: I plan to } \\
\text { Sit at the back combination of different approaches to providing } \\
\quad \text { feedback. }\end{array}$ & $\begin{array}{l}\text { Observer's reflective log, teacher's reflective diary, teachers' } \\
\text { comments on observer's notes, the audio recording of } \\
\text { post-observation sessions }\end{array}$ \\
\hline
\end{tabular}
3.1.1 Implementation Cycle: 1

The purpose of diagnostic observation was to identify the areas of specific focus for subsequent observations. During the pre-observation session, I discussed the observation checklist with the teachers. (See Appendix 4) I conducted the observation and post-observation sessions and found that teachers do not know what critical events are. Therefore, I explained that critical events might be when not "anything goes according to plan, goes very successfully, any student asks an unexpected question or anything that teacher feels could be done in another way etc. (Wragg 1999) I identified the critical events of the lesson that I observed (See Appendix 5) as Copeland (1982) says, "Some teachers need to be told when they first begin to teach. (In Gebhard. 1990) In the feedback session, I also discussed the focus of the next observation with the teachers as Meyer et al. (1965) suggest, "Mutual goal setting, not criticism, improves performance (In Bollington et al. 1990).

\subsubsection{Implementation Cycle: 2}

The purpose of this cycle was to help the teachers to identify critical events on their own. This time I used an observation checklist that has clearly identified the areas to look into a teacher's practice. (See Appendix 6) After the observations, when asked about the critical events, teachers were able to identify the critical events from the lessons. However, teachers could not think about the reasons why these events happened. Teacher A said,

"I think when I distributed the resources, was a critical time. I could not hold my students' attention before giving the instruction so they did not listen to me carefully and started working. That's why I kept on passing instructions throughout the activity."

[Unedited teacher's work]

By the end of the second cycle, I found that though teachers were not able to do the critical analysis of their practices, asking about the critical events was helpful in terms of finding their ability to identify critical events in their lessons.

\subsubsection{Implementation Cycle: 3}

In this cycle, I gave some suggestions to improve the proposed lesson plans during the pre-observation session and teachers showed a willingness to try out new strategies in their classes. After conducting the pre-observation meeting, I expected that my suggestions would work for both the teachers. However, I found that teacher A was comfortable to 
try out the proposed strategy in her class as compared to teacher B. She said,

"I feel good that the idea worked out well and my students have started working in groups and most of the students were able to do the task, though still there are some issues like noise level and some hyper students who finished early and created a disturbance in the class."

[Unedited teacher's work]

In contrast to teacher $\mathrm{A}$, teacher $\mathrm{B}$ changed the strategy and switched back to her previous methodology in the middle of the lesson telling me, "You see I was right that this strategy would not work with these students, I know them very well." Here I found that teacher B has a very strong influence of "blame-shifting". There is another factor that has its influence and that is her mindset about the students of the particular class. This not only affects a teacher's ability to analyse the strategy critically but students' learning is also affected.

\subsubsection{Implementation Cycle: 4}

In the fourth cycle, I worked with teachers and co-planned the lessons, including setting the objectives and planning the tasks. This worked well and I found that this time teacher B felt confident and completed the planned task with her students. After the observation, I gave my observation notes to the teachers and asked them to reflect upon them before coming to the feedback session. Ur (1999) says that the first and most important basis for professional progress is simply the teachers' own reflection on daily classroom events. So, she gives emphasis to personal progress by reflecting on one's own activities and practices that happened in the class. Here, I found that the provision of observation notes not only helped the teachers reflect on their practices, but also strengthened the relationship of trust and confidence with me. During the feedback, teachers reflected critically and proposed the areas for the next observation on their own. For instance, teacher A mentioned the equal distribution of work to individual students in a group and its impact on students' interactions and individual learning. Together with teachers, I planned to video record the next lesson as it offers a powerful opportunity for reflection on one's practice and works best when the focus is a group of pupils or teacher only, as suggested by Barnette et al. (2002), Moon (1999), Turney et al. (1982) and Wragg (1999).

\subsubsection{Implementation Cycle: 5}

The purpose of this cycle was to provide the teachers a chance to look critically and begin to raise questions about their practices accordingly. Vakalisa and Gawe (2011) contend that reflective teaching offers teachers the opportunity to renew their practice and to understand the effects of their teaching. They further stated that reflective teaching provides information on how teachers connect with learners meaningfully thus promoting sound teaching and learning practice. Akbari (2007) suggests that reflective teaching will make teachers question clichés that they have learned during their formative years and will also enable them to develop more informed practice. I recorded the lessons on video and asked them to watch the recorded lessons and write their reflections on the given self-evaluation sheet before they come for feedback. (See Appendix 7) I found that video recordings of the lessons provide very useful information for reflection. While watching their own video recordings, teachers can develop an awareness of their own teaching. A teacher may do many things in class, but may not be aware of many things happening in the class, which the teacher may not normally see. A classroom video can vividly picture the whole process of teaching. It can trigger teachers' reflective thinking and help them get some inspiration and ideas for improvement. Teachers also found this experience really helpful as they reflected upon their practices more critically and also began to think of alternatives on their own. (See Appendix 8) I also found that video recordings reduced the fear of the observer being judgmental towards their practices as they could see the things happening in their classrooms themselves. It also encouraged them to initiate and lead the feedback session as Freeman (1982) and Gebhard (1984) emphasize the importance of allowing the teacher to lead the discussion.

\subsection{Post-Intervention Phase}

\subsubsection{Analysis of Teachers' Level of Reflection}

After conducting five observations of each teacher, I asked them some questions to analyse their level of reflection. (See Appendix 9) I also used a framework (See Appendix 1) to evaluate the objectives of using classroom observation as a tool for teachers' professional development. I found that the framework was not helpful to analyse teachers' learning or development because a teacher, after moving to the next step, sometimes slides back to an earlier stage. Hence, teachers' learning abilities or skills to reflect cannot be boxed into any of the levels mentioned in the framework. So I did not use the framework, rather used an analysis grid to see the level of reflection. (See Appendix 10) During the first cycle, teachers could neither identify critical events nor analyse their practices; rather Published by Sciedu Press 
their views were more general and descriptive. (See Appendix 11) However, by the end of the fifth cycle teachers started raising questions and thinking of various alternatives about their practices.

The following process of helping the teachers through classroom observation has emerged from my project. The process identifies the steps grounded in classroom practices. It is likely that these steps do not occur in a sequence; neither all of these can be followed in one session.

Table 5. The Process of Helping Teachers through Observation

\section{The following process of helping the teachers through observation emerged from my project}

1. Pre-observation meeting; teachers shared their proposed lesson plans and I, as a facilitator, extended help where needed.

2. Observation

3. Identification and sharing of critical events during the post-observation session. Teachers and observer both shared the identified critical events.

4. Selection of one or all events to reflect upon.

5. An oral critical inquiry of objectives, planning, and implications by:

a. Posing questions (open-ended)

b. Sharing experiences

c. Explaining any related theory

d. Identifying what still needs to be improved

e. Drawing implications

f. Sharing alternatives and hypothesizing their consequences

g. Motivating to take an initiative

h. Giving suggestions/input

i. Agreeing on the next step

6. Taking notes of important points, alternative teaching strategies and lessons learned for future reference.

7. Planning next.

\section{Lessons Learnt and Further Action Plan}

The critical role that the teacher educator or a cooperating teacher plays is to assist the teachers to be successful in engaging in reflective practices. Nolan and Huber (1989) state that the aims of supervision (teacher educator) are: (1) engaging the teacher in the process of reflective behaviour while (2) fostering critical inquiry into the process of teaching and learning, thereby (3) increasing the teachers' understanding of teaching practice and (4) broadening and deepening the repertoire of images and metaphors the teacher can utilize to deal with problems. By incorporating students' reflections with their own reflections and considering the stable data provided by the participant-observer, teachers were able to better understand classroom events (Nolan \& Huber, 1989). Through research opportunity, readings, reflection, dialogue and collaboration I have explored different ideas and perspectives about teaching and learning process. A brief summary of major findings and lessons learnt from the project, process, learning of teachers and my own learning is presented as follows;

i) Teachers found the pre and post-observation sessions very useful for their professional development. (See Appendix 12) These sessions also help the observer to understand the roots of the teacher's classroom problems. Identification of critical events and reflecting upon them is proved quite helpful to teachers.

ii) Cyclical observations provided teachers the courage and intellectual capacity to turn their focus upon improved actions and they also developed a good range of strategies.

iii) Teachers perceived my role as a helper, facilitator and a resource person who could provide suggestions and alternatives, where required. (See Appendix 12) 
iv) I found that trust, openness and a non-judgmental stance are the key attitudes to have an effective observation aiming at the teachers' professional development.

v) Creating time for pre and post-observation sessions in the current school practice was very challenging. Teachers were used to doing all their marking and writing lesson plans during free lessons, so taking away this "free" time disturbed their work schedules.

vi) Teachers' less availability issue was also faced when they were sent to substitute lessons. As a result, I conducted the post-observation sessions after the school hours, which increased their staying time at school.

Based on my findings and challenges that I faced during the project I plan to follow the subsequent action plan.

- Conduct a workshop before starting the observation cycle to cover some theoretical aspects of the purposes of observation.

- Plan the observations bi-weekly, so that teachers are not stressed out.

- Share my entire schedule of pre and post-observation sessions along with the observation schedule with the school administration to avoid managerial issues. However, the feedback of the observations would not be shared with the school administration because the purpose of these observations is to help the teachers develop their skills, not the assessment.

- Time for the post-observation sessions needs to be carved out within the school timing.

- Develop in myself a reflective attitude and self-criticism when helping the teachers to develop their own practical theory.

\section{Recommendation and Further Research}

The study indicates that classroom observation is potentially a useful tool for the professional development of teachers and works best when the personal capacity of a teacher, an observer, and school provide a base for the effective use and outcome for teachers. I feel the need to explore further how reflective conversations between a teacher and an observer affect individual teacher's attitudes and behaviour. This will highlight what needs to be done further to improve individual competencies and practices as Ghaye and Ghaye (1998) say that reflective conversation in the context of teaching and learning enables teachers to see "future teaching possibilities." However, I feel that a co-teaching experience can also provide a valuable basis for collaborative inquiry. It might raise a range of interesting issues and questions for using reflective conversation in planning and teaching and improving this strategy.

\section{References}

Acheson, K., \& Gall, M. (1980). Techniques in the Clinical Supervision of Teachers. New York: Longman.

Akbari, R. (2007). Reflection on Reflection: A Critical Appraisal of Reflective Practice in L2 Teacher Education. System, 35(2), 192-207. https://doi.org/10.1016/j.system.2006.12.008

Barnette, M., Harwood, W., Keating, T., \& Saam, J. (2002). Using emerging technologies to help bridge the gap between university theory and classroom practice: Challenges and success. School Science and Mathematics, 20(6), 299-313. https://doi.org/10.1111/j.1949-8594.2002.tb17887.x

Bollington, R., Hopkins, D., \& West, M. (1990). An Introduction to Teacher Appraisal. London: Cassell.

Bulman, C., Lathlean, J., \& Gobbi, M. (2014). The process of teaching and learning about reflection: Research insights from a professional nurse education. Studies in Higher Education, 39(7), 1219-1236. https://doi.org/10.1080/03075079.2013.777413

Canada-Phillips, S. (2014). A physical educators use of Freirian praxis for critical reflection. Physical Educator, 71(4), 635-643.

Cogan, M. (1973). Clinical Supervision. Boston: Houghton Mifflin.

Collin, S., Karsenti, T., \& Komis, V. (2013). Reflective practice in initial teacher training: Critiques and perspectives. Reflective Practice, 14(1), 104-117. https://doi.org/10.1080/14623943.2012.732935

Dervent, F. (2015). The effect of reflective thinking on the teaching practices of preservice physical education teachers. Issues in Educational Research, 25(3), 260-275.

Dewey, J. (1993). How we think: A restatement of the relation of reflective thinking to the education process. Chicago: 
Henry Regnery.

Edge, J. (1992). Co-operative development: professional Self-development through Co-operation with Challenges. Harlow. UK: Longman.

Fook, J., \& Gardner, F. (2007). Practising Critical Reflection: A Resource Handbook. Maidenhead: Open University Press.

Freeman, D. (1982). Observing Teachers: Three Approaches to In-Service Training and Development. TESOL Quarterly, 16(1). https://doi.org/10.2307/3586560

Gaies, S., \& Bowers, R. (1990). Clinical supervision of language teaching: the supervisor as trainer and educator. In Richards, J.C and D. Nunan (Eds) Second Language Teacher Education. Cambridge: Cambridge University Press.

Gebhard, J. (1984). Models of Supervision: choices. TESOL Quarterly, 18(3). https://doi.org/10.2307/3586717

Gebhard, J. (1990). Models of Supervision: choices. In Richards, J. C., D. Nunan (eds) Second Language Teacher Education. Cambridge: Cambridge University Press.

Ghaye, A., \& Ghaye, K. (1998). Teaching and learning through reflective practice. London: David Fulton.

Goldhammer, R. (1969). Clinical Supervision: Special Methods for the Supervision of Teachers. New York: Holt Rinehart \& Winston.

Handal, G., \& Louvas, P. (1987). Promoting Reflective Teaching: Supervision in action. England: Open University Press.

Hargreaves, K. (2016). Reflection in medical education. Journal of University Teaching\& Learning Practice, 13(2), 1-19.

Hickson, H. (2011). Critical reflection: Reflecting on learning to be reflective. Reflective Practice, 12(6), 829-839. https://doi.org/10.1080/14623943.2011.616687

Jacobs, M., Vakalisa, N. C. G., \& Gawe, N. (2011). Teaching-Learning Dynamics. Cape Town: Pearson.

Körkkö, M., Kyrö-Ämmälä, O., \& Turunen, T. (2016). Professional development through the reflection in teacher education. Teaching and Teacher Education, 55, 198-206. https://doi.org/10.1016/j.tate.2016.01.014

Labrie, A., Brdarevic, V., \& Russell, T. (2000). Shared reflection on teacher education practices: Teaching and Learning in a pre-service physics method course. Reflective Practice, 1(2), 231-245. https://doi.org/10.1080/713693149

Lewis, A. J., \& Miel, A. (1972). Supervision for Improved Instruction: New Challenges. Belmont: Wadsworth.

Liu, K. (2015). Critical reflection as a framework for transformative learning in teacher education. Educational Review, 67(2), 135-157. https://doi.org/10.1080/00131911.2013.839546

Maingay, P. (1988). Observation for Training, Development or Assessment? In Duff, T. (1988) Exploration in Teacher Training. Harlow. UK: Longman.

Malderez, A., \& Bodoczky, C. (1999). Mentor Courses: A resource book for trainer-trainers. Cambridge: Cambridge University Press.

McGarr, O., \& McCormack, O. (2014). Reflecting to conform? Exploring Irish student teachers' discourses in reflective practice. Journal of Educational Research, I 07(4), 267. https://doi.org/10.1080/00220671.2013.807489

McLeod, N. (2015). Reflecting on reflection: Improving teachers' readiness to facilitate participatory learning with young children. Professional Development in Education, 41(2), 254-272. https://doi.org/10.1080/19415257.2013.805306

Moon, J. A. (1999). Reflection in Learning \& Professional development: Theory \& Practice. London: Kogan Page.

Nolan, J., \& Huber, T. (1989). Nurturing the reflective practitioner through instructional supervision: A review of the literature. Journal of Curriculum and Supervision, 4(2), 126-145.

Paterson, C., \& Chapman, J. (2013). Enhancing skills of critical reflection to evidence learning in professional practice. Physical Therapy in Sport, 14(3), 33-138. https://doi.org/10.1016/j.ptsp.2013.03.004

Randall, M., \& Thornton, B. (2001). Advising and Supporting Teachers. Cambridge: Cambridge University Press. 
Rarieya, J. (2005). Promoting and investigating students' uptake of reflective practice: A Pakistan case. Reflective Practice, 6(2), 285-294. https://doi.org/10.1080/14623940500106518

Roberts, A. (2009). Encouraging reflective practice in periods of professional workplace experience: The development of a conceptual model. Reflective Practice, 10(5), 633-644. https://doi.org/10.1080/14623940903290703

Schon, D. (1983). The reflective practitioner: How professionals think in action. London: Temple Smith.

Turney, C., Cairns, L. G., Ettis, K. J., Hatton, N., Thew, D. M., Towler, J., \& Wright, R. (1982). Supervisor Development Programmes. Sydney: Sydney University Press.

Ur, P., (1999). A Course in Language Teaching: Practice and Theory. Cambridge: CUP. https://doi.org/10.1017/CBO9780511732928

Wajnryb, R. (1992). Classroom Observation Tasks. Cambridge: Cambridge University Press.

Williamson, A. M., Mears, A., \& Bustos, C. (2015). Reflection tools in teacher education classes: An analysis of implementation in online, hybrid, and tradition1 environments. Turkish Online Journal of Educational Technology, 14(2), 138-143.

Wragg, E. C. (1993a) Primary Classroom Skills. London: Routledge.

Wragg, E. C. (1999). An Introduction to Classroom Observation. London: Routledge. $2^{\text {nd }}$ edition.

Wragg, E. C. (ed) (1984) Classroom Teaching Skills. London: Croom Helm. https://doi.org/10.4324/9780203325445

Wragg, E. C., Wikeley, F. J., Wragg, C. M., \& Haynes, G. S. (1996) Teacher Appraisal Observed. London: Routledge.

Wragg, E. C., Wragg, C. M., Haynes G. S., \& Chamberlin, R. A. (1998). Improving Literacy in the Primary School. London: Routledge.

Zeichner, K. M., \& Liston, D. P. (1996). Reflective teaching: An introduction. Mahwah, NJ: Lawrence Erlbaum.

\section{Appendix 1}

Framework to Analyse Teachers' Level of Reflection

\begin{tabular}{|l|l|}
\hline Level of Reflection & Representation/Indicators of Reflection \\
\hline 4. Transformative & $\begin{array}{l}\text { Restructured learning } \\
\text { Ability to see its applicability }\end{array}$ \\
& $\begin{array}{l}\text { Issues are looked at both, the micro and macro levels and from various } \\
\text { dimensions, e.g. ethical, moral, political, social etc. }\end{array}$ \\
\hline 3. Making meaning & $\begin{array}{l}\text { Meaningful reflections } \\
\text { Ability to identify the purpose } \\
\text { Explanations with principle or theory are given as the rationale } \\
\text { Occasionally looks at issues outsides the class, but linked to classroom activities. }\end{array}$ \\
\hline 2. Making sense & $\begin{array}{l}\text { Highly descriptive of ideas that stuck him or her } \\
\text { Critical events are described but not analysed } \\
\text { Events are labelled with the appropriate terms }\end{array}$ \\
\hline 1. Noticing & $\begin{array}{l}\text { Factual description } \\
\text { No details are given } \\
\text { Simply outlines what happened } \\
\text { Skeletal wordings. }\end{array}$ \\
\hline
\end{tabular}

Source: Rarieya, 2005 (an adaptation of Bax and Cullen's (2003) table on stages of learning during a teacher's adoption of reflective practice) 


\section{Appendix 2}

\section{Brief Profile of the Participants}

\section{Teacher A}

Teacher A is teaching English to grade two and has one year of experience. She has a Masters degree in Education from a well known public university in Karachi, Pakistan. She is also a member of Society of Pakistan English Language Teachers (SPELT). She joined the school without any professional or pre-service education. It is her first experience of teaching.

\section{Teacher B}

Teacher B is teaching English to grade three and is hired recently. She has a Masters degree in English Language \& Literature from a public university in Punjab, Pakistan. She too has joined the school without any professional or pre-service education or certificate.

\section{Appendix 3}

\section{Consent Form}

I, ........... teach English to grade........ at ..............school. I agree to take part in the practical project titled "Classroom Observation as a tool for Professional Development" undertaken by Ms. Aisha Siddiqua. I have read the brief description of the research, provided by Ms. Aisha Siddiqua. During this study, my classes will be observed and I will have pre and post-observation sessions with her too. I assure that during the study I will make all the efforts to be available for the activities connected to the study. I agree that I will give all the relevant information and support to facilitate the research. I grant permission for pre and post- observation sessions and interviews to be recorded. I will not be identified as the source of any information I give, by name, position, and institutional affiliation. I grant permission to the researcher to use the data for any academic/professional purposes. I know that I have the right to withdraw from this study without any penalty.

\section{Appendix 4}

Observation Checklist

Name:

Period:

Subject:

Topic/Area:

What led up to the event?
Date:

Class:

Time:

Student Strength:

What happened?

What was the outcome?

Interview with the participant.

Source: Wragg, E. C. (1999) An Introduction to Classroom Observation. London: Routledge. $2^{\text {nd }}$ edition. 
Appendix 5

Observer's Notes from the Observation Checklist

\section{Teacher A}

\section{What happened?}

- The teacher divided the students into groups of five students each and asked to identify three and four letter words using shape pattern from the given text.

- She gave them sheets and asked to use any five words in sentences in groups.

- She distributed the resources first and gave the instructions about the task later. Therefore, students did not hear the teacher and started arguing loudly because everyone wanted to choose the clue cards individually.

- Five students got completely lost and attempted the task differently as they could not understand well what they were asked to do.

- The teacher gave 20 minutes to complete the task, whereas many students could not complete until the last minute of the lesson, so she could not get time to wrap up the lesson. In the end, she told the students that they will continue the task in the lesson the next day.

\section{Teacher B}

\section{What happened?}

- The teacher asked the students to underline all the words they find difficult in the story.

- She asked meanings of the underlined words and wrote them on the board.

- She asked the students to copy down all the words with their meanings. It took 35 minutes to note down all the words in notebooks.

- Next, she asked the students to read the story in pairs the remaining 15 minutes. However, 7 students out of 20 were not willing to do so and they requested her not to read the story. Students looked exhausted while copying the words with meaning, so lost their interest in reading.

\section{Appendix 6}

\section{Classroom Observation Checklist for Teacher A}

Teacher:

Date:

Class:

Time:

\section{Managing Group work}

\begin{tabular}{|l|l|l|}
\hline \multicolumn{1}{|c|}{ Sub-skill } & Observation & \\
\hline i) Organizing groups, & & \\
seating, etc. & & \\
ii) Instructions & & \\
iii) Appointing, briefing & & \\
leaders & & \\
\hline
\end{tabular}




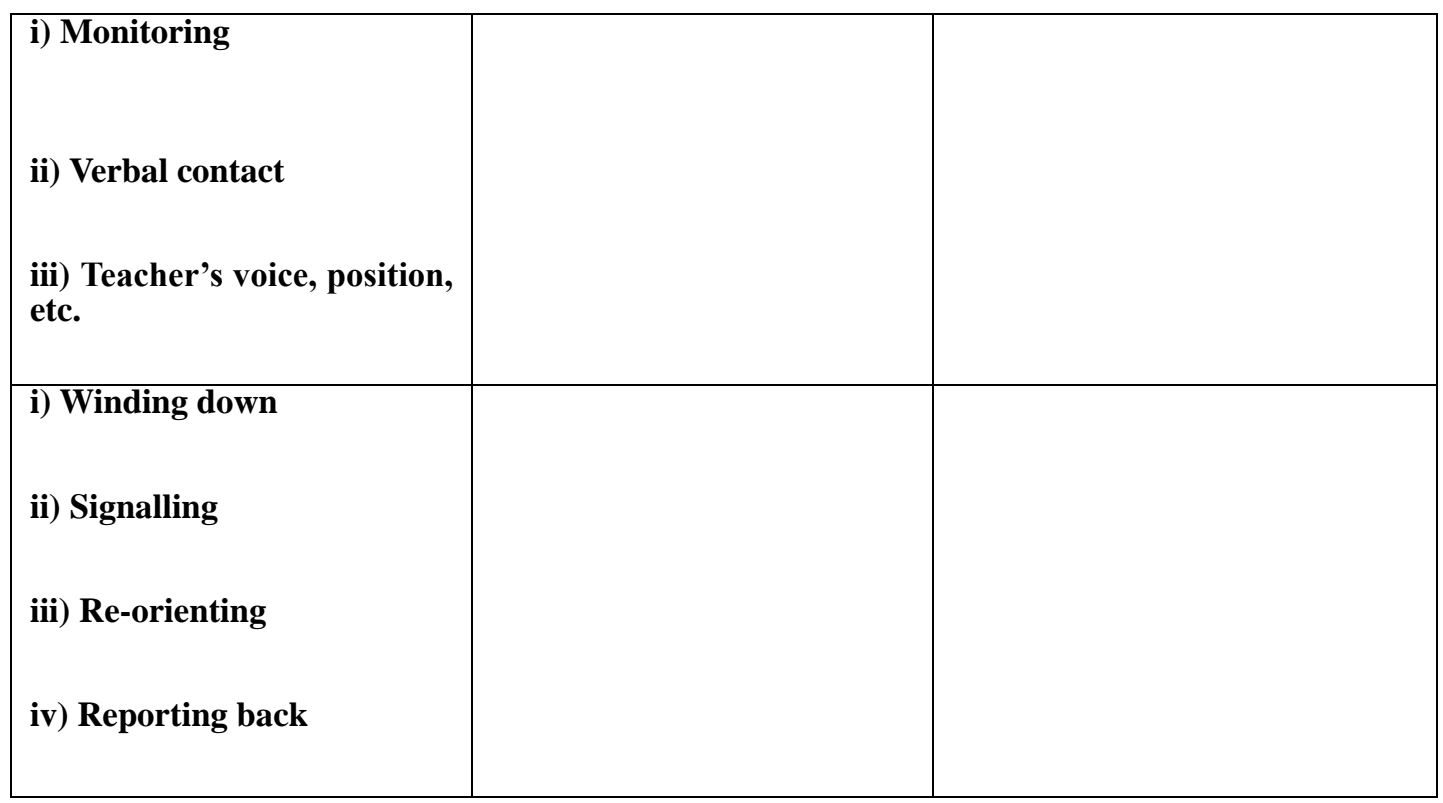

Source: Wajnryb, R. (1992) Classroom Observation Tasks. Cambridge: Cambridge University Press.

\section{Classroom Observation Checklist for Teacher B}

Teacher:

Class:

Topic:
Date:

Time:

Subject:

\begin{tabular}{|l|l|l|l|}
\hline Sample & & $\begin{array}{l}\text { Supplementary } \\
\text { Support }\end{array}$ & + - \\
\hline Teacher question & & & \\
Student response & & & \\
$\begin{array}{l}\text { Teacher feedback } \\
\text { Seedback response to }\end{array}$ & & & \\
& & & \\
\hline
\end{tabular}

Source: Wajnryb, R. (1992) Classroom Observation Tasks. Cambridge: Cambridge University Press. 
Appendix 7

Self-Observation Schedule

(Adapted from a schedule compiled by the Institute of Education, London University, 1984) Observation for development of and by self

Seven key questions

1. WHAT WERE THE BEST POINTS OF THE LESSON?

\begin{tabular}{|l|l|}
\hline BEST POINTS & REASON \\
\hline & \\
\hline
\end{tabular}

2. WHAT DID STUDENTS ACTUALLY DO? (Write, speak, play, sing, etc.)

\begin{tabular}{|l|c|c|l|}
\hline WHAT THEY DID & $\begin{array}{c}\text { \% OF CLASS } \\
\text { INVOLVED }\end{array}$ & $\begin{array}{c}\text { WHAT I'D } \\
\text { PLANNED FOR } \\
\text { THEM TO DO }\end{array}$ & $\begin{array}{c}\text { HOW DID WHAT I DID } \\
\text { AFFECT THIS? }\end{array}$ \\
\hline & & & \\
\hline
\end{tabular}

3. WHAT DID THEY LEARN?

\begin{tabular}{|c|c|c|c|}
\hline $\begin{array}{c}\text { WHAT THEY } \\
\text { LEARNT }\end{array}$ & EVIDENCE & $\begin{array}{c}\text { WHAT I'D } \\
\text { PLANNED FOR } \\
\text { THEM TO LEARN }\end{array}$ & $\begin{array}{c}\text { REASONS FOR ANY } \\
\text { DIFFERENCES }\end{array}$ \\
\hline & & & \\
\hline
\end{tabular}

4. HOW WORTHWHILE WERE THE ACTIVITIES?

\begin{tabular}{|c|c|c|}
\hline ACTIVITY & GRADE (1-5) & HOW COULD I IMPROVE OR REPLACE \\
IT?
\end{tabular}

5. WHAT HAVE I LEARNT?

\begin{tabular}{|c|c|}
\hline $\begin{array}{c}\text { WHAT DID I DISCOVER IN THE } \\
\text { LESSON? }\end{array}$ & $\begin{array}{c}\text { WHAT HAVE I DISCOVERED ON } \\
\text { REFLECTION? }\end{array}$ \\
\hline & \\
\hline
\end{tabular}

\section{WHAT DO I INTEND TO DO NOW?}

\section{ACTION POINTS:}

\section{HOW DO I FEEL, HAVING OBSERVED MYSELF}

Source: Malderez, A. and C. Bodoczky (1999) Mentor Courses: A resource book for trainer-trainers. Cambridge: Cambridge University Press. 


\section{Appendix 8}

\section{An Extract from Teacher A's Reflective Diary}

I have realized that it is extremely difficult to provide differentiation within the classroom and spending quality time with each group appears to be impossible. Another issue that needs to be reflected upon is the provision of differentiated tasks for the slow learners. During this teaching unit I feel that I have spent more time with the high/average achievers, therefore the slow learners have been neglected. This means that children are being held back, therefore I need to devise a system to ensure all children have equal quality time spent with them. Due to this, I aim to focus on one group each day.

After reflecting on this teaching unit I feel that it is important to devise another strategy to assist the students to infer or deduce the definitions of the target vocabulary. Therefore, I plan to produce a word bank or some clue cards with sample sentences that can be placed on each table for students' help. This will also need to be differentiated so as the slow learners do not have any difficulty while reading the given words or guessing meanings of the target words through clue cards.

[Unedited teacher's work]

\section{Appendix 9}

\section{Questions that I Used for Post-Intervention Phase}

1. What did you intend to achieve by attending this professional event?

2. Did you find it useful in achieving these objectives? (And how?)

3. How did you find the cyclical observation as a strategy for teachers' professional development? (benefits, challenges, opinions)

4. What do you think of my role in this process?

5. How could the content have been made more valuable for you?

6. How might the sessions have been better managed?

7. Do you think teachers can be engaged in such activities for their professional development? Why/why not?

8. What kind of follow up would be useful for you? 
Appendix 10

Analysis Grid

\begin{tabular}{|c|l|l|l|l|}
\hline $\begin{array}{c}\text { Classroom observation as a } \\
\text { tool for professional support }\end{array}$ & $\begin{array}{c}\text { Teachers' } \\
\text { responses }\end{array}$ & $\begin{array}{c}\text { My role as an } \\
\text { observer }\end{array}$ & $\begin{array}{c}\text { Hindering } \\
\text { factors }\end{array}$ & $\begin{array}{c}\text { Facilitating } \\
\text { factors }\end{array}$ \\
\hline Writing critical events & & & & \\
\hline $\begin{array}{c}\text { Questions: } \\
\text { a) 'Why' questions } \\
\text { b) Probing questions } \\
\text { c) Challenging views }\end{array}$ & & & & \\
\hline $\begin{array}{c}\text { Linking reflective } \\
\text { conversation with critical } \\
\text { incidents and prior } \\
\text { experiences }\end{array}$ & & & & \\
\hline $\begin{array}{c}\text { Sharing experiences } \\
\end{array}$ & & & & \\
\hline Giving suggestions/input & & & & \\
\hline
\end{tabular}

\section{Appendix 11}

\section{A Sample Analysis of Teachers' Level of Reflection}

\begin{tabular}{|c|c|}
\hline Writing critical events & $\begin{array}{l}\text { Learning from the last conversation, this time I asked the teacher to identify the critical event. It } \\
\text { was quite encouraging that the teacher was able to identify the critical event, though critical } \\
\text { analysis is not done. I also identified the critical events during the observation and shared with her. } \\
\text { Critical events identified by me were different from what the teacher B had identified. }\end{array}$ \\
\hline Teachers' responses & $\begin{array}{l}\text { Teacher B identified the critical event in the class, however; she is still unable to come out of the } \\
\text { blame shifting phenomenon. Such as, "still I found that they were not interested in reading, they do } \\
\text { not like reading. Maybe the vocabulary was quite dry for them. But as I knew, it is quite dry so I } \\
\text { gave all the main words at the start which were important for them. They were, you know, most of } \\
\text { them were looking lazy and not interested in the task given to them." }\end{array}$ \\
\hline My role as an observer & An arbitrator, a provider of alternative aspects, suggesting a possible solution to problems. \\
\hline Hindering factors & $\begin{array}{l}\text { I think that teacher B has a very strong influence of "blame-shifting". There is another factor that } \\
\text { has its influence and that is her mindset about the students of grade III. She says that these students } \\
\text { do not participate in the lesson and are very lazy. This affects not only a teacher's ability to analyze } \\
\text { the strategy critically, but students' learning is also affected. }\end{array}$ \\
\hline Facilitating factors & $\begin{array}{l}\text { Asking about the critical events from the teacher was helpful in terms of finding their ability to } \\
\text { identify critical events from her class. }\end{array}$ \\
\hline
\end{tabular}




\section{A Sample Analysis of Teachers' Level of Reflection}

\begin{tabular}{|l|l|}
\hline Questions: & $\begin{array}{l}\text { This time I kept myself more focused on questions. I asked the teacher to rationalize } \\
\text { her actions in the class, such as, "Your objective was to make the students understand } \\
\text { the inferential meanings and differentiate between the facts and opinions, whereas you } \\
\text { read the text and explained yourself. How do you see about asking the students to read } \\
\text { themselves as your objective was to make students read and infer? At this stage, } \\
\text { students need an explanation of concepts. Like, if in today's class you could have given } \\
\text { examples of facts and opinions. It would have worked," }\end{array}$ \\
\hline Teachers' responses & $\begin{array}{l}\text { Questions were helpful in identifying many gaps in teacher's knowledge, thinking, and } \\
\text { attitude. It is not only for an observer, but the teacher must also raise questions once } \\
\text { they learn some skill. I found that there is a gap in teacher's knowledge regarding } \\
\text { lesson objectives. The teacher gave three statements of the objective for the same } \\
\text { lesson; i) to find out what is fact and opinion. } \\
\text { ii) to find out inferential meanings from the text. } \\
\text { iii) Inferential meanings, while taking help from facts and opinions. }\end{array}$ \\
\hline My role as an observer & Critical friend, a facilitator, a partner in dialogue, helping to clarify. \\
\hline Hindering factors & $\begin{array}{l}\text { I think the lack of clarity of objectives does not allow the teacher to look at her } \\
\text { practices critically. If the teacher is not clear about the objectives she cannot reflect and } \\
\text { rationalize her practices. }\end{array}$ \\
\hline Facilitating factors & $\begin{array}{l}\text { The questions were helpful in probing the teacher's thinking. If questioning is } \\
\text { continued during pre and post- observation sessions, a teacher might develop the skills } \\
\text { to reflect upon her practices critically. }\end{array}$ \\
\hline
\end{tabular}

A Sample Analysis of Teachers' Level of Reflection

\begin{tabular}{|c|c|}
\hline $\begin{array}{l}\text { Giving } \\
\text { input: }\end{array}$ & $\begin{array}{l}\text { Providing suggestions or input is another aspect to fill the gaps in teachers' knowledge } \\
\text { and skills. Teachers took note of the alternative strategies that were shared during the } \\
\text { discussions and implemented in their classes, e.g. I noticed that teacher A stands at one } \\
\text { place during the whole period. Students who are sitting at the back, who created a } \\
\text { disturbance, took advantage of this and she was also not able to monitor what } \\
\text { happened there so I suggested her to move around while explaining and teaching } \\
\text { something. I also asked her to make some classroom rules while involving the students } \\
\text { and ensure that students follow them. }\end{array}$ \\
\hline Teachers' responses & $\begin{array}{l}\text { I found that both the teachers are motivated by the suggestions that I gave them. It is } \\
\text { not only giving and accepting rather they asked me questions regarding their issues and } \\
\text { decided to incorporate the changes into their classes. When teacher B complained } \\
\text { about the minimum involvement of students, I suggested her to throw the questions in } \\
\text { the class equally. In the beginning, tell them and keep reminding them that you can ask } \\
\text { anyone. I hope it will work because sometimes students feel bored if they have to listen } \\
\text { only. Give them the focus of the task, interest develops. }\end{array}$ \\
\hline My role as an observer & Facilitator, critical friend. \\
\hline Hindering factors & $\begin{array}{l}\text { I feel that teaching experience matters here. Teachers develop a range of teaching } \\
\text { strategies with experience. }\end{array}$ \\
\hline Facilitating factors & $\begin{array}{l}\text { Exposure to new teaching strategies. Teachers like suggestions and activities and want } \\
\text { to try them out with their students. When I shared my experience of using pre-reading } \\
\text { strategies, they also showed interest to apply them. }\end{array}$ \\
\hline
\end{tabular}




\section{Appendix 12}

\section{Teachers' Feedback on Pre and Post-Observation Discussions}

\section{Teacher A:}

The experience of working with you during pre and post-observation sessions was interesting. I like it, in fact, it was helpful. At times I did not understand, but you suggested me different strategies and especially that "rules setting". I found it very useful because I did make the rules for my students, but you encouraged me that I need to involve my students while making the classroom rules so that they take the ownership. It worked out well. I have tried different other strategies that you suggested to me during the pre and post- observation sessions.

\section{Teacher B:}

After the first observation, when I was coming to the feedback session I was feeling quite scared and did not want to discuss the things. The problem was, this particular class made me quite disappointed. They never cooperate with me. So, I was not interested in talking about that, but when we discussed, it became interesting and quite useful. I found these sessions really helpful.

\section{Teachers' Feedback on My Role as an Observer}

\section{Teacher A:}

I would call you a helper who gives suggestions about doing the same thing in different other ways. You were pretty helpful for me and I think that these kinds of sessions should be conducted especially at the beginning of the year.

\section{Teacher B:}

Your role is very important. It is of great help. Sometimes I found you a resource person who provides suggestions, who is working with us and together we explored the teaching practices. In the beginning, I felt quite worried and once I stopped the planned activity and continued with the old one, but your encouragement motivated me so well that I felt normal in the next lesson and tried a new strategy.

[Unedited teachers' work] 